\title{
Diagnosis and management of systemic hypertension due to renovascular and aortic stenosis in patients with Williams-Beuren syndrome
}

\author{
Erika Arai Furusawa, MD, PhD ${ }^{1}$ \\ Camila Sanches Lanetzki Esposito, MD ${ }^{1}$ \\ Rachel Sayuri Honjo, MD, PhD ${ }^{2}$ \\ Lisa Suzuki, MD, PhD \\ Gabriela Nunes Leal, $P h D^{3}$ \\ Chong Ae Kim, MD, PhD² \\ Benita Galassi Soares Schvartsman, MD, PhD'
}

\begin{abstract}
1. Pediatric Nephrology Unit, Institute of Children, Hospital das Clínicas, Faculty of Medicine, University of São Paulo, São Paulo, Brasil. 2. Genetics Unit, Institute of Children, Hospital das Clínicas, Faculty of Medicine, University of São Paulo, São Paulo, Brasil.
\end{abstract} 3. Radiology Unit, Institute of Children, Hospital das Clínicas, Faculty of Medicine, University of São Paulo, São Paulo, Brasil.

http://dx.doi.org/10.1590/1806-9282.64.08.723

SUMMARY

AIM: To describe the incidence, diagnosis, and management of systemic arterial hypertension related to renal artery stenosis in patients with Williams-Beuren syndrome.

METHODS: Sixty-five patients with Williams-Beuren syndrome were evaluated for hypertension. Enrolled patients underwent Doppler sonography of the renal arteries and Doppler echocardiography. Those with Doppler sonography-detected lesions or with normal Doppler sonography but severe hypertension underwent computed tomography or gadolinium-enhanced magnetic resonance angiography of the aorta and renal vessels. Patients needing vascular therapeutic intervention underwent conventional angiography.

RESULTS: Systemic arterial hypertension was diagnosed in 21/65 patients with Williams-Beuren syndrome (32\%; 13 male) with a mean age of 13.9 years (5mo-20yrs). In 8/21 patients renovascular hypertension was detected. Angioplasty was unsuccessful in five patients with renal artery stenosis, requiring additional treatment. Doppler echocardiography showed cardiac abnormalities in 16/21 (76\%) hypertensive patients.

CONCLUSION: Cardiac abnormalities and hypertension in patients with Williams-Beuren syndrome are common. Thus, thorough evaluation and follow-up are necessary to reduce cardiovascular risks and mortality of these patients

KEYWORDS: children, hypertension, renal artery stenosis, Williams-Beuren syndrome

\section{INTRODUCTION}

Williams-Beuren syndrome (WBS) is a genetic disorder characterized by facial dysmorphisms, congenital heart defects, growth retardation, infantile hypercalcemia, renal and vascular abnormalities, and intellectual disability ${ }^{1}$. Clinical diagnosis is usually performed during childhood when the typical facial changes and cognitive profile become more apparent $^{1}$ (Figure 1). Genetic confirmation can be carried out using FISH $^{2}$ (fluorescence in situ hybridization) ${ }^{\text {or }} \mathrm{MLPA}^{3}$ (multiplex ligation-dependent probe amplification), or microarray tests for identification of the causal microdeletion at $7 q 11.23$. Urinary tract system abnormalities in WBS have been described in approximately $18 \%$ of patients ${ }^{4,5,6}$ and include renal 
ectopia, hydronephrosis, renal agenesis or hypoplasia, vesicoureteral reflux, and voiding dysfunction. Nephrocalcinosis, proteinuria, and chronic renal failure have also been reported in some cases series ${ }^{4,5,6}$

Cardiovascular abnormalities are also quite common in patients with WBS and have been observed in more than $80 \%$ of cases ${ }^{7,8}$. Supravalvular aortic stenosis (SVAS) is the most frequent abnormality, with an estimated incidence of $64 \%^{(\mathbf{9}, 10)}$. Systemic arterial abnormalities include localized or diffuse narrowing of the thoracic or abdominal aorta, coronary, renal and other visceral arteries ${ }^{11,12}$. According to Lacolley et al. ${ }^{13}$ vascular injury in patients with WBS may be associated with reduced elastin synthesis and increased proliferation of vascular smooth muscle cells.

Arterial hypertension arterial (SAH) is also observed with high prevalence in $\mathrm{WBS}^{14}$. In a minority of patients, renal artery stenosis, diffuse narrowing of the aorta, aortic coarctation or a combination of these abnormalities have been implicated ${ }^{4,5}$. Renal artery stenosis is usually found at the origin of the renal arteries $^{7}$ (Figure 2). Nonetheless, there are few reports about the origin and management of SAH in WBS, and the diagnosis is often not made.

This study aimed to describe the incidence of hypertension among 65 patients with WBS, as well as the diagnosis and management of hypertension due to renovascular or aortic stenosis.

\section{METHODS}

Sixty-five patients who were being treated from 1993 to 2010 at the Pediatric Nephrology and Genetics Units at the Institute of Children, Hospital das

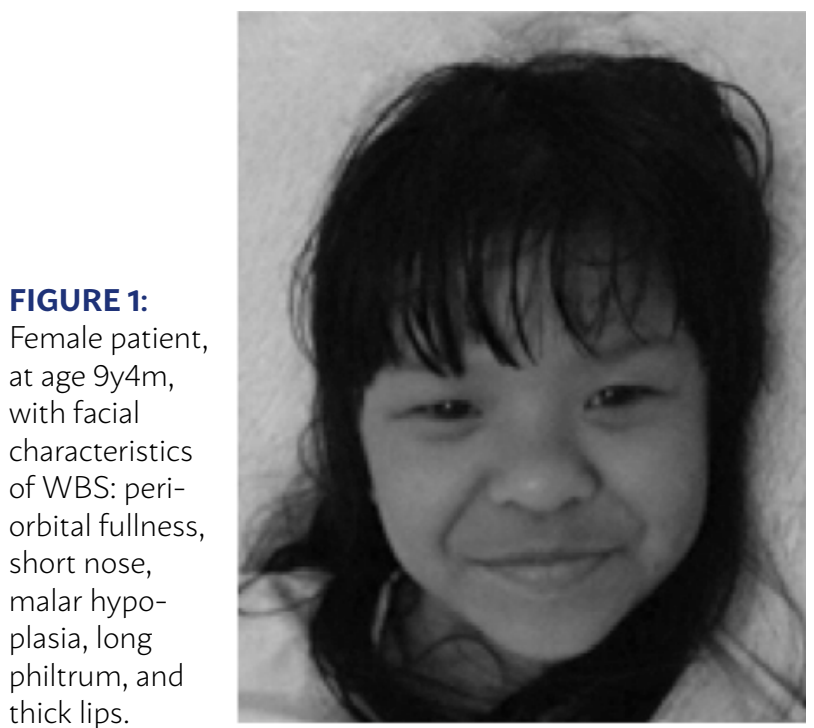

Clínicas of the Faculty of Medicine of the University of São Paulo were included in this study. All patients were diagnosed with WBS based on clinical findings and had the presence of the $7 q 11.23$ microdeletion confirmed by the FISH (2) or MLPA test (with a specific kit for WBS) ${ }^{(3)}$.

Patients with blood pressure (BP) values at or above the 95th percentile for age, gender, and height confirmed on 3 different occasions ${ }^{15}$ were included in the study and followed prospectively. Clinical and laboratory parameters such as the age of onset of hypertension, associated symptoms, baseline BP, fundus examination, microalbuminuria/creatinine ${ }^{16}$ and calcium/creatinine ratio ${ }^{17}$ in spot urine samples, estimated creatinine clearance ${ }^{18}$, and serum ionized calcium were evaluated.

All enrolled patients were initially investigated by Doppler echocardiography(DE) and renal ultrasound (RU) with color-flow Doppler sonography of the renal arteries (DS). Those with findings of renal artery stenosis $^{19}$ or hypertension stage $\mathrm{II}^{15}$ with a normal DS underwent computed tomographic angiography $(\mathrm{CTA})^{(20)}$ and/or gadolinium-enhanced magnetic resonance angiography (MRA) of the aorta and renal vessels ${ }^{21}$. Patients with unclear diagnosis by CTA and/or MRA or who required vascular therapeutic intervention (angioplasty) underwent conventional angiography (CA).

\section{RESULTS}

Of the 65 patients with WBS included in this study, 21 (32\%; mean age of 13.9 years, range: 5 months to 20 years, 13 males) had hypertension and

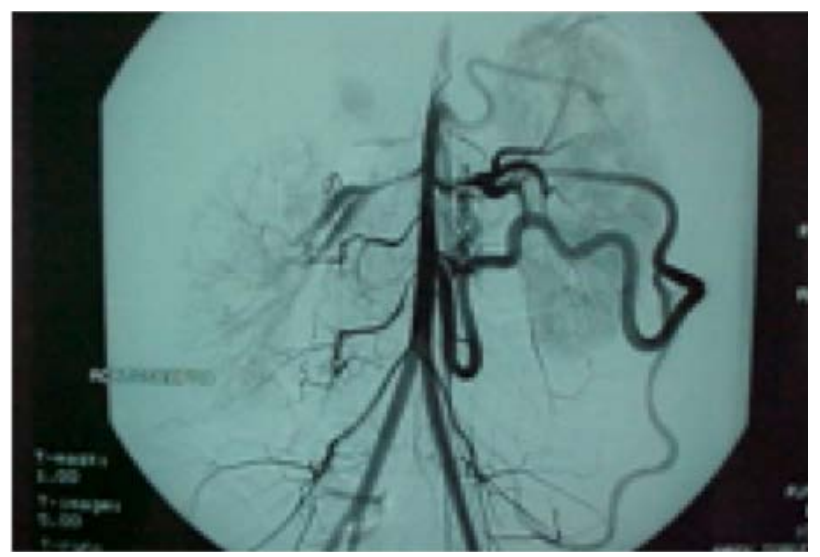

FIGURE 2: Digital subtraction angiography demonstrates discreet stenosis of the abdominal aorta anda severe stenosis of the left and right renal arteries. Also note several collateral arteries from the aorta on the left side 
were submitted to further imaging studies. In this group, the mean age at WBS diagnosis was 5.2 years (ranging from 8 months to 12 years). All patients were asymptomatic, and hypertension was detected by active investigation during routine medical visits.

The evaluation of the renal arteries by DS was normal in 12/21 patients. Of these, five patients did not undergo a CTA or MRA scan because of a low clinical suspicion of hypertension due to renovascular or aortic stenosis. In these five patients, BP was adequately controlled with one or two medications, and none had secondary involvement of target organs during follow-up. Of the 12 patients with normal DS results, seven had persistent severe hypertension and were therefore submitted to further testing. Two of them had findings consistent with SAH associated with vascular stenosis, as detected by CTA and conventional arteriography (one had abdominal aorta narrowing, and the other had right renal artery stenosis), indicating that DS resulted in false negative results for these patients. The remaining five patients had normal CTA results.

Nine patients with DS suggesting renal artery stenosis were also submitted to CTA or MRA, and only six patients had vascular lesions confirmed by one of these methods. In three patients, the DS yielded false positive results. Of the 21 hypertensive patients, 16 underwent DS followed by complementary renal and aortic vascular investigation with CTA or MRA. The DS showed discordant results when compared with CTA or MRA in five of those patients (31\%).

TABLE 1: RENAL AND AORTIC VASCULAR LESIONS IN 8/21 PATIENTS WITH WILLIAMS-BEUREN SYNDROME AND SYSTEMIC ARTERIAL HYPERTENSION.

\begin{tabular}{l|l|l} 
& Patients & Type of lesion \\
\hline Renal artery stenosis & 6 & $\begin{array}{l}\text { unilateral 2 / } \\
\text { bilateral 4* }\end{array}$ \\
\hline Aorta coarctation & 1 & thoracic \\
\hline Diffuse aorta narrowing & 1 & $\begin{array}{l}\text { descendent and } \\
\text { abdominal }\end{array}$ \\
\hline
\end{tabular}

${ }^{*}$ One patient also had aortic stenosis.

TABLE 2: ECHOCARDIOGRAPHIC FEATURES IN THE 21 WBS PATIENTS WITH SYSTEMIC ARTERIAL HYPERTENSION.

\begin{tabular}{l|l} 
Echocardiographic features & $\mathrm{n}(\%)$ \\
\hline Supravalvular aortic stenosis & $10(47.6 \%)$ \\
\hline Mitral valve prolapse & $6(28.6 \%)$ \\
\hline Normal & $5(24 \%)$ \\
\hline
\end{tabular}

Hypertension associated with renal or aortic lesions was confirmed in 8/21 patients (Table 1), corresponding to $12 \%$ of the cases of WBS and $38 \%$ of patients with arterial hypertension. Renal artery stenosis was detected in six patients (28.6\%), aortic coarctation in one patient, and diffuse narrowing of the aorta in another one. One patient with renal artery stenosis also had aortic stenosis.

Percutaneous transluminal balloon angioplasty was performed in five patients with renal artery stenosis, and it was unilateral in two and bilateral in three patients. In one patient with bilateral stenosis, a stent was placed in the renal arteries. All four patients who underwent angioplasty had treatment failure, and two of them required surgical intervention for stenosis correction. An aortorenal graft was performed in one patient. For another patient who had stenosis of both renal arteries and of the aorta, an iliac renal graft, as well as a graft of the descending aorta to the infrarenal abdominal aorta, were inserted. Two patients who did not undergo surgical intervention continued with conservative treatment with antihypertensive medications (amlodipine, carvedilol, hydralazine, and diuretic). Two patients with lesions of the aorta underwent surgical correction.

All patients underwent DE at the initial examination, and the alterations found are described in Table 2. SVAS was the most prevalent malformation (46\%). Two patients underwent surgical correction of SVAS and had mitral valve regurgitation, eccentric left ventricular hypertrophy, and left ventricular systolic dysfunction. Three patients with mitral valve prolapse also had eccentric left ventricular hypertrophy and left ventricular systolic dysfunction.

Hypercalciuria was found in four patients, and hypercalcemia was diagnosed in one patient. Estimated creatinine clearance and albuminuria at the beginning of the study are shown in Table 3. One patient had hypertension after clinically presenting hemolytic uremic syndrome. Unilateral pyelocalyceal dilatation was observed in $2 / 21$ patients submitted to renal sonography.

In this series, three patients died during follow-up due to heart failure: one patient with surgically corrected SVAS, one with both bilateral renal artery and aortic stenosis who had been submitted to angioplasty and iliac-renal and aortic grafts, and one with SVAS who died following heart transplantation. 
TABLE 3: LABORATORY FEATURES (MEAN; RANGE) IN 21 PATIENTS WITH WBS AND ARTERIAL HYPERTENSION.

\begin{tabular}{|c|c|}
\hline Laboratory features & $\begin{array}{l}\text { Mean; range } \\
\mathrm{n}\end{array}$ \\
\hline $\begin{array}{l}\text { Serum ionized calcium } \\
\text { Hypercalcemiaa }\end{array}$ & $\begin{array}{l}1.23(1.1-1.4) \mathrm{mmol} / \mathrm{L} \\
1\end{array}$ \\
\hline $\begin{array}{l}\text { Urinary calcium } \\
\text { Hypercalciuriab }\end{array}$ & $\begin{array}{l}0.15(0-0.94) \mathrm{mg} / \mathrm{mg} \text { creatinine } \\
4\end{array}$ \\
\hline $\begin{array}{l}\text { eGFRc } \\
\text { CKD class } \|\end{array}$ & $\begin{array}{l}118.23(68-183) \mathrm{ml} / \mathrm{min} / 1.73 \mathrm{~m}^{2} \\
3\end{array}$ \\
\hline $\begin{array}{l}\text { Albuminuria } \\
\text { Microalbuminuria d }\end{array}$ & $\begin{array}{l}13.31 \text { (3.55-36.79) mg/g creatinine } \\
1\end{array}$ \\
\hline
\end{tabular}

\section{DISCUSSION}

WBS is a congenital multisystem disease affecting the cardiovascular system, nervous system, and connective tissues that often involves hypertension, although the etiology of this symptom is not fully understood. Possible explanations include disorganization of the elastic layer and hypertrophy of smooth muscle cells and collagen fibers. As a result, diffuse or localized progressive narrowing of the arterial wall leads to increased arterial stiffness and sympathetic activity ${ }^{23}$. The prevalence of hypertension in WBS is widely variable $e^{4,5,6,8,14}$ (5 to $70 \%$ in series including all ages and 5 to $46 \%$ in children). It can appear as early as infancy, but the average age of diagnosis varies from 6.5 to 38 years. In the present study, the incidence of hypertension was $32 \%$, with a mean age of diagnosis of 13.9 years (range: 5 months to 20 years). As observed by other authors ${ }^{8}$, we confirmed that patients with WBS are initially asymptomatic for hypertension, which highlights the need for health professionals to actively measure BP in these children in all routine visits.

In the present study, which included only children and adolescents, systemic arterial hypertension associated with vascular stenosis was observed in $8 / 21$ hypertensive patients (38\%), which included renal artery stenosis (28.6\%) and aortic lesions. In the literature; the frequency of arterial stenosis is variable across case series (e.g., 2 to $70 \%)^{5,8,12,14,22}$.

Renal DS is usually indicated as an initial diagnostic method for screening of arterial stenosis. It is a non-invasive, relatively inexpensive test that is available in most centers but may have a high rate of technical failure (approximately 30\%) ${ }^{24}$ because it is an operator-dependent method that also requires patients' cooperation. In our study, we found a simi- lar failure rate for DS (31\%). The main difficulties are the detection of intra-renal and bilateral stenosis, the presence of obesity and the inadequate preparation of the patient. In WBS, psychomotor and behavioral disorders (agitation and anxiety) may represent additional complications ${ }^{1}$. The sensitivity and specificity of DS in the detection of vascular stenosis have been shown to be between 60 and $98 \%$ and between 62 and $98 \%$, respectively ${ }^{24 ; 25}$. It should be emphasized that the current sample was too small, since we conducted further imaging tests only on severely hypertensive patients, hindering this type of analysis.

Computed tomographic angiography or MRA is commonly used in patients with WBS, but these techniques are not always available and require sedation or general anesthesia in children. MRA has high sensitivity (64-93\%) and specificity (72-97\%) $)^{25,26}$ but may overestimate renal arterial lesions or underdiagnose intra-renal lesions. On the other hand, CTA requires the use of iodinated contrast and ionizing radiation. Most of our patients underwent CTA because of the limited availability of the MRA equipment at our unit. However, we were unable to establish the accuracy of these methods in our study, because only some of the patients who received MRA or CTA also underwent CA, which is considered the gold standard in the diagnosis of arterial stenosis ${ }^{21}$.

Angioplasty was performed in five patients with stenosis of the renal artery but was unsuccessful, as observed by other authors ${ }^{26,27}$. Patients with aortic coarctation or stenosis were treated with surgical correction, with graft insertion in severe cases.

Other causes of hypertension such as hypercalcemia, renal scarring secondary to recurrent urinary infections, obesity, and essential hypertension may also be involved in hypertension in WBS. Hypercalcemia is frequently described in WBS ${ }^{29}$ and occurred transiently in one patient in this study. It may manifest early or later in life, and patients should, therefore, be periodically monitored for possible calcium disturbances ${ }^{1,6,9}$. Broder et al. ${ }^{30}$ found a higher incidence of hypertension in patients with infantile hypercalcemia, but to date, no direct links between hypertension and hypercalcemia have been established.

Congenital cardiovascular abnormalities are prevalent in patients with WBS and can occur in about $75 \%$ of cases ${ }^{7,8}$. SVAS is the most prevalent disease, and is also present in up to $75 \%$ of cases $^{9,14,30}$. Mitral valve prolapse, bicuspid aortic valve, and coronary abnormalities have also been described ${ }^{10,11,12}$. SVAS 
may be severe in up to $30 \%$ of patients ${ }^{30}$, and surgical correction is necessary in such cases ${ }^{27}$. Consistent with earlier reports ${ }^{10,12,23}$, the most common cardiovascular abnormality observed in our study was SVAS, and it was severe in two patients who required surgical intervention.

\section{CONCLUSION}

Hypertension is a common finding in children with WBS and should be tested and investigated routinely as early as possible in this population. We recommend that CTA or MRA be used whenever possible for cases of severe hypertension.

\section{RESUMO}

OBJETIVO: Descrever a incidência, o diagnóstico e o tratamento da hipertensão arterial sistêmica relacionada com estenose da artéria renal em pacientes com síndrome de Williams-Beuren.

MÉTODOS: Sessenta e cinco pacientes com síndrome de Williams-Beuren foram avaliados quanto à presença de hipertensão. Os pacientes foram submetidos à ultrassonografia com Doppler das artérias renais e ecocardiograma Doppler. Aqueles com suspeita de hipertensão renovascular foram submetidos à tomografia computadorizada ou angiografia por ressonância magnética da aorta e vasos renais ou angiografia convencional.

RESULTADOS: A hipertensão arterial sistêmica foi diagnosticada em 21/65 pacientes com síndrome de Williams-Beuren (32\%, 13 do sexo masculino), com idade média de 13,9 anos (5 meses-20 anos). Em 8/21 pacientes foi detectada a hipertensão renovascular. Angioplastia não teve sucesso em cinco pacientes com estenose da artéria renal, necessitando de tratamento adicional. O ecocardiograma Doppler mostrou anormalidades cardíacas em 16/21 (76\%) pacientes hipertensos.

CONCLUSÃO: As anormalidades cardíacas e hipertensão arterial em pacientes com síndrome de Williams-Beuren são muito frequentes, sendo necessários uma avaliação minuciosa e seguimento para diminuir o risco cardiovascular e a morbimortalidade desses pacientes

PALAVRAS-Chave: Criança. Hipertensão. Estenose de artéria renal. Síndrome de Williams-Beuren.

\section{REFERENCES}

1. American Academy of Pediatrics: Health care supervision for children with Williams syndrome. Pediatrics 2001; 107: 1192-204.

2. Borg I, Delhanty JD, Baraitser M. Detection of hemizygosity at the elastin locus by FISH analysis as a diagnostic test in both classical and atypical cases of Williams syndrome. J Med Genet 1995; 32: 692-696.

3. Dutra RL, Pieri Pde C, Teixeira AC, Honjo RS, Bertola DR, Kim CA. Detection of deletions at 7q11.23 in Williams- Beuren syndrome by polymorphic markers. Clinics (Sao Paulo) 2011; 66: 959-964.

4. Sugayama SM, Koch VH, Furusawa EA, Leone C, Kim CA. Renal and urinary findings in 20 patients with Williams-Beuren syndrome diagnosed by fluorescence in situ hybridization ( FISH). Rev Fac Med Hosp Clin Sao Paulo 2004; 59: 266-272.

5. Pankau R, Partsch C), Winter M, Gosch A, Wessel A. Incidence and spectrum of renal abnormalities in Williams-Beurens syndrome. Am / Med Genet 1996; 63: 301-304.

6. Pober BR, Lacro RV, Rice C, Mandell V, Teele RL. Renal finding in 40 individuals with Williams syndrome. Am J Med Genet 1993; 46: 271-274.

7. Donnai D, Karmiloff-Smith A. Williams syndrome. From genotype through to the cognitive phenoype. Am / Med Genet 2000; 97: 164-171.

8. Bouchired $K$, Boyer $O$, Bonnet D, Brunelle F, Decramer S, Landthaler G et al. Clinical features and management of arterial hypertension in children with Williams-Beuren syndrome. Nephrol Dial Transplant 2010; 25: 434-438

9. Morris CA. Williams Syndrome. 1999 Apr 9 [Updated 2013 Jun 13]. In: Pagon RA, Adam MP, Ardinger HH, et al., editors. GeneReviews ${ }^{\circledR}$ [Internet]. Seattle (WA): University of Washington, Seattle; 1993-2014. Available from: http://www.ncbi.nlm.nih.gov/books/NBK1249/

10. Vernant $P$, Corone P, Rossignol AM, Bielman C. 120 cases of the Williams and Beuren syndrome. Arch Mal Coer Vaiss 1980; 73: 661-666.

11. Bernand Y, Didier D, Bozio A, Champsaur G, Renaud JC, Maurat JP. Coronary anomalies associated with the Williams-Beuren syndrome. Apros of 2 cases. Arch Mal Coeur Vaiss 1985; 78: 791-795.

12. Zalzstein E, Moes CA, Musewe NN, Freedom RM. Spectrum of cardiovascular anomalies Williams-Beuren syndrome. Pediatr Cardiol 1991; 12: 219-223.

13. Lacolley P, Boutouyrie P, Glukhova M, Daniel Lamaziere JM, Plouin PF, Bruneval $P$ et al. Disruption of the elastin gene in adult Williams syn- drome is accompanied by a paradoxical reduction in arterial stiffness. Clin Sci (Lond) 2002; 103: 21-29.

14. Honjo RS, Dutra RL, Furusawa EA, Zanardo EA, Costa LSA, Kulikowski LD, Bertola DR, Kim AE. Williams-beurens syndrome: A clinical study of 55 brazilian patients and the diagnosis use of MLPA. Biomed Res Int. 2015:903175

15. National High Blood Pressure Program Working Group on High Blood Pressure in Children and Adolescents. The fourth report on the diagnosis, evaluation and treatment of high blood pressure in children and adolescents. Pediatrics 2004; 114: 555-576.

16. Karalliedde J, Vibert G. Microalbuminuria and cardiovascular risk. Am / Hypertens 2004; 17(10): 989-93

17. Butani $L$, Kalia A. Idiopathic hypercalciuria in children-how valid are the existing diagnostic criteria? Pediatric Nephrol 2004; 19: 577-582.

18. Schwartz G), Haycock GB, Edelmann CM Jr, Spitzer A. A simple estimate of glomerular filtration rate in children derived from body length and plasma creatinine. Pediatrics 1976; 58:259-263.

19. Granata A, Fiorinin E, Andrulli S, Loggias F, Gallieni M, Sicurezza E et al. Doppler ultrasound and renal artery stenosis: An overview. / Ultrasound 2009; 12: 133-143.

20. Kurian J, Epelman M, Darge K, Meyers K, Nijs E, Hellinger JC. The role of CT angiography in the evaluation of pediatric renovascular hypertension. Pediatr Radiol 2013; 43: 490-501.

21. O'Neill WC, Bardelli M, Yevzlin AS. Imaging for renovascular disease. Se2min Nephrol 2011; 31(3): 272-282.

22. KDIGO 2012 Clinical practice guideline for the evaluation and management of chronic kidney disease. Kidney Int Supp/ 2013; 3:1-150.

23. Collins RT $2^{\text {nd }}$, Kaplan P, Somes GW, Rome II. Long-term outcomes of patients with cardiovascular abnormalities and Williams syndrome. Am J Cardiol 2010; 105: 874-878.

24. Wessel A, Pankau R, Kececioglu D, Ruschewski W, Bursch JH. Three decades of follow up of aortic and pulmonary vascular lesions in the Williams-Beuren syndrome. Am J Med Genet 1994; 52: 297-301.

25. Conkbayir I, Yucesoy C, Edguer T, Yanik B, Yasar AU, Hekimoglu B. Doppler sonography in renal artery stenosis. An evaluation of intrarenal and extrarenal imaging parameters. Clin Imaging 2003; 27: 256-260.

26. Rountas C, Vlychou M, Vassiou K, Liakopoulos V, Kapsalaki E, Koukoulis G 
et al. Imaging modalities for renal artery stenosis in suspected renovascular hypertension: prospective intraindividual comparison of color Doppler US, CT angiography, GD-enhanced MR angiography, and digital subtraction angiography. Ren Fail 2007; 29: 295-302.

27. Actis Dato GM, La Torre M, Caimmi P, Actios Dato A /r., Centofanti P, Ottino GM et al. Williams-Beuren syndrome. Long-term results of surgical treatments in six patients. / Cardiovasc Surg (Torino) 1997; 38: 125-129.

28. Kumada Y, Yasuda H, Sasaki E, Murakawa S, Mori Y, Hirose H. Reoperation for diffuse supravalvar aortic stenosis with Williams syndrome-extended path aortoplasty and extra-anatomic bypass from the ascending aorta to the descending aorta in a median sternotomy. I Thorac Cardiovasc Surg 1998; 46: 1061-1064.

29. Udwin O. A survey of adults with Williams syndrome and idiopathic infantile hypercalcaemia. Dev Med Child Neurol 1990; 32: 129-141.

30. Broder K, Reinhardt E, Ahern J, et al. Elevated ambulatory blood pressure in 20 subjects with Williams syndrome. Am / Med Genet 1999; 83: 356-360 